\title{
Considerações acerca do falo e sua incidência nas estruturas clínicas
}

\section{Some notes about the phallus and its incidence on clinical structures}

\section{Vera Pollo*}

Psicanalista (AME) da Escola de Psicanálise dos Fóruns do Campo Lacaniano, Rio de Janeiro, RJ, Brasil

\begin{abstract}
RESUMO
O presente texto discute o lugar e a função do falo no cerne da teoria psicanalítica: desde a "fase fálica do desenvolvimento da libido" (FREUD, 1923) até o "quadro lógico da sexuação" que divide os seres falantes em dois lados: "lado homem" ou gozo "todo fálico" e "lado mulher" ou gozo "não-todo fálico" (LACAN, 1972-73). Dois importantes autores da literatura universal, Antonin Artaud e Yukio Mishima, e um menino de treze anos, Miguel, são convocados pelo autor para ilustrar os seguintes temas: o falo zerado, na psicose, o desmentido perverso e a transformação do falo em significante do desejo, na neurose.
\end{abstract}

Palavras-chave: Falo, Castração, Sexuação, Gozo, Significante.

\begin{abstract}
This text discusses the place and the fonction of the phallus in the Center of psychoanalytical theory: from "the phallic phase of libido's development" (FREUD, 1923) to "Iogic schema of sexualization" (LACAN, 1972-73) that distributes those who speak in two sides: "man side" or "all phallic" jouissance and "womn side" or "not-all phallic" jouissance. Two important authors of universal literature, Antonin Artaud and Yukio Mishima, and a thirteen years boy, named Miguel, are invited by the author to illustrate the following themes: the phallus equal zero in the psychosis, the denial of perversion and the phallus transformation into the significant of the desire in neurosis.
\end{abstract}

Keywords: Phallus, Castration, Sexuation, Jouissance, Significant.

"O que une os seres é o amor, o que os separa é a Sexualidade. Somente o Homem e A Mulher que podem unir-se acima de toda sexualidade são fortes."

Antonin Artaud, 1937.

Uma das mais antigas acusações à doutrina freudiana, mas que ainda ganha adeptos em nossos dias, é a de seu falocentrismo. Acreditamos ser possível demonstrar que nem Freud nem Lacan procurariam refutá-la. Caso contrário, não teriam se ocupado, cada 
um por seu turno, em esclarecer a função do falo no que concerne à assunção do sexo próprio.

Não é nosso objetivo retomar os termos da crítica acima mencionada. No entanto queremos observar que, se há muitos anos as feministas estigmatizam o escândalo que, afinal de contas, se resume no encontro de dois termos, a mulher e o Falo, numerosos cultos atestam que este último é "um sagrado fundamental, talvez mesmo o sagrado por excelência." (CLÉMENT; KRISTEVA, 2001, p. 76). Mas, que lugar ocupa exatamente o falo no cerne da doutrina psicanalítica? Como verificar sua incidência nas três estruturas clínicas reconhecidas pela psicanálise? Será que o entendimento da função do falo pode nos ajudar no diagnóstico diferencial: psicose, perversão e neurose?

Freud (1905) não demorou a verificar que o advento da posição viril, assim como da posição feminina, resulta de um longo percurso que parte de uma disposição bissexual e de um modo de satisfação dito "perverso polimórfico". As posições masculina e/ou feminina dependem do encontro com a castração, em primeiro lugar, a castração da mãe. A menina, em particular, precisará escolher o pai e o falo, como forma de desgarrar-se da mãe. Todavia ela não pode permanecer nesta escolha, pois, se nela já estão presentes componentes claramente sensuais, a posição de filha sobrepõe-se ainda à de mulher. O menino, tampouco, pode ficar agarrado ao seu pequeno falo imaginário, ou não superará a vivência de ameaça à virilidade.

Desde os primeiros anos de seu ensino, Lacan assinalou que os impasses de Freud $^{1}$ em concluir as análises que conduzia tinham a ver com as relações sujeito-falo da ordem do 'ser' ${ }^{2}$, as quais denotam uma forma bem precoce do desejo: o desejo de ser o falo materno imaginário. As relações do tipo "ser ou não ser", resquício em cada um de nós da dúvida trágica e hamletiana, são logicamente anteriores às relações da ordem do 'ter'. Ao retomar a proposição de Lacan (1958), segundo a qual a função fálica enuncia que ou um sujeito tem o falo ou ele o é, Bruno (1999) declara que ela se inscreve na série inaugurada por duas teses freudianas: a de que não há um equivalente feminino do falo e a de que o pai gozador não está submetido à função fálica. Em outros termos, a função fálica se fundamenta em uma exceção.

A psicanálise ensina que se pode desejar ser o falo de alguém e que esta é a posição do sujeito histérico, cujo desejo é permanecer como "precioso objeto de discurso" (LACAN, 1969-70, p. 32). Ensina, também, que a completude fálica é uma das características da maternidade, já que o filho pode se prestar a ocupar o lugar de metonímia do desejo do Outro materno e apêndice do corpo da mãe. É então, mais do que nunca, que a mãe/mulher é um sujeito que "tem o falo!". 
Contudo, diferentemente do que pode parecer à primeira vista, a falicização do filho costuma ser benéfica. Aliás, do ponto de vista do advento do sujeito, ela é mesmo imprescindível e se inscreve no que Freud (1914) identificou como satisfação narcísica dos pais. Prova-o, entre outros testemunhos, o conteúdo do delírio paranoico do Presidente Schreber. Ele não se esclarece pela ausência de simbolização do órgão peniano, mas pelo fato de que, "na impossibilidade de ser o falo que falta à mãe, resta-lhe a solução de ser a mulher que falta aos homens" (LACAN, 1998, p. 572).

\section{O ser-para-o-sexo e a função do falo}

Certamente, Freud não foi o primeiro a falar na existência de apetite sexual na infância. Mas, se o conceito freudiano de sexualidade é radicalmente novo, se Lacan o reconhece como altamente subversivo, até mesmo escandaloso, isso se deve ao fato de que jamais se havia estabelecido de forma tão clara a estreita dependência do significante e do gozo sexual. Em outras palavras, nunca se afirmara, até então, que a sexualidade é simultaneamente infantil e intelectual.

Bem cedo se esclarece "o elo faltoso" na teoria freudiana da histeria, ou seja, a importância da identificação com a pessoa amada na determinação da corrente alo-erótica da libido. Mas, somente nos anos 1920, Freud conclui que o Édipo completo, isto é, com suas versões positiva e invertida, implica quatro identificações: duas masculinas e duas femininas. E verifica que um sujeito se posicionará como homem ou mulher em consequência da força relativa de suas identificações por ocasião da dissolução do Édipo. Porém, uma coisa é o que se pode chamar de "caráter sexual mental ou posição sexual", outra é a escolha de objeto ou parceiro sexual que não segue necessariamente a mesma direção da primeira. A identificação sexual não é suficiente para dizer o sexo. A tosse de Dora permanece um exemplo paradigmático, pois, embora expresse claramente o desejo sexual pelo genitor do sexo oposto, não é suficiente para fazer dela uma mulher.

Se o inconsciente não conhece a diferença dos sexos enquanto tal, somente o falo introduz nele uma dialética. Freud (1923) descobriu primeiramente "a fase fálica do desenvolvimento da libido", em que meninos e meninas dividem os seres humanos em apenas duas classes: a dos seres masculinos ou portadores do falo, e a dos seres femininos ou castrados. Em seguida, adverte os psicanalistas de que "o significado do complexo de castração só pode ser corretamente apreciado se sua origem na fase da primazia fálica for também levada em consideração" (Ibid., p. 182). Por fim, em seu texto de 1927, "Fetichismo", deixa claro que todas as crianças desenvolvem a crença em uma mãe fálica até o momento em que a observação dos órgãos genitais da mulher estabelece um "conflito entre o peso da percepção desagradável e a força de seu contradesejo", cujo resultado pode ser 
a formação de um compromisso - um dos nomes freudianos do sintoma -, "tal como só é possível sob o domínio das leis inconscientes do pensamento - o processo primário." (FREUD, 1927, p. 181).

É fato que, até o fim de sua obra, Freud referiu-se muitas vezes ao falo como sinônimo de pênis, mas é fato também que, asseverando que o falo das mulheres é o protótipo do fetiche, conferiu-lhe uma conotação mais ampla. Ao seguir na trilha freudiana, Lacan (1958) demonstrou que as identificações sexuais estão diretamente ligadas ao significante falo, o qual "irrealiza" a relação entre os sexos. E também que a "primazia fálica", como Freud a nomeara, é responsável por fazer do jogo de sedução entre os sexos um autêntico jogo de semblantes: um "parecer ser", para as mulheres; um "parecer ter", para os homens. Por esta razão, prossegue Lacan (Idem), o sexo dos falantes nada tem de physis, natureza, mas de sexus, do latim secare, isto é, secar. Já o verbo parecer, remetendo ao separere, traduz-se também por partir-se, separar-se. Eis o ponto de origem da sex ratio, ou partilha homem/mulher.

Em 9 de maio de 1958, Lacan profere uma conferência no Instituto Max Planck de Munique sob o título Die Bedeutung des Phallus, "A significação do falo". Nessa ocasião, ele lembra que, se para Freud o falo não é uma fantasia, nem um objeto parcial, para os antigos ele é um simulacro, divindade pagã, ídolo ou esfinge. Em um caso como em outro, ele é algo que deve ser mantido sob o véu e cuja função depende inclusive desse velamento. Sua revelação "era reservada aos Mistérios". Lacan comenta ainda que no mistério antigo, conforme o demonstra a célebre pintura da Villa de Pompéia, no exato momento em que o falo é desvelado, aparece Aidos (SCHAM), o demônio do pudor.

Em seus termos, o falo é o significante que "no conjunto dos significantes, designa o lugar do significado" (LACAN, 1958, p. 697). Mais precisamente, aquele cuja "incidência sobre o significável" determina o significante como significado. Pode-se então dizê-lo o significante do fluxo vital, do que se transmite de uma a outra geração. Se a turgidez do pênis no coito o torna propício para simbolizar o falo, o membro viril não passa, no entanto, de um "precário suporte imaginário". O texto lacaniano localiza o falo nos três registros da experiência subjetiva: o real, o simbólico e o imaginário. Neste, a criança pode oferecer-se por inteira, isto é, com todo o seu corpo, para satisfazer o desejo materno, quando este é um desejo metonímico de falo, portanto, que passa ininterruptamente de um a outro objeto. No simbólico, o falo é um significante privilegiado, significante ímpar que direciona a cadeia dos significantes sem nela comparecer. É um elemento que adquire valência negativa, negativiza-se na passagem do imaginário ao simbólico, ou seja, um sujeito não pode manter-se no lugar de "ser o 
falo materno imaginário" e, ao mesmo tempo, "ter o falo" como significante do desejo. Então, Lacan dirá que a relação do sujeito com o falo é da ordem do "não sem" ou que ele "não é sem tê-lo". Compara-o ao elemento tipográfico: o que há de mais saliente na cópula lógica, em que o verbo ser separa de tal modo sujeito e atributo, que estes já não podem ser idênticos. Velado, o falo faz signo, ou seja, representa alguma coisa para alguém. E inaugura a Aufhebung do sujeito, sua suspensão como sujeito do desejo e do gozo.

A função do falo é determinar as estruturas - ritos, gestos e falas que serão submetidas às relações entre os sexos. Para mascarar a falta fálica, o parecer vem substituir o ter.

É para ser o falo, isto é, o significante do desejo do Outro, que a mulher vai rejeitar uma parcela essencial da feminilidade, nomeadamente, todos os seus atributos na mascarada. É pelo que ela não é que ela pretende ser desejada, ao mesmo tempo que amada." (LACAN, 1958, p. 701).

Ao substituir o significante freudiano 'sexualidade' por 'sexuação', Lacan (1972-73) escreve - ou matemiza, se preferirmos - a divisão homem/mulher em uma forma que, evidentemente, nada tem a ver com o sexo dito cromossômico, mas com o modo como o ser falante diz gozar na relação com o outro. A psicanálise verifica que estar fora da partilha homem/mulher equivale a estar fora-do-sexo. Testemunham-no os sujeitos psicóticos, que nela só se inscrevem mediante a invenção de uma sexualidade inédita.

A divisão dos seres falantes entre um lado todo fálico e um lado nãotodo fálico não significa de modo algum que outros gozos não sejam experimentados. Porém, toda vez que se quer significar um gozo qualquer ou fazê-lo entrar na linguagem, o que comparece é justamente o gozo fálico. E assim, o discurso analítico demonstra que "o Falo é a objeção de consciência, feita por um dos dois seres sexuados, ao serviço a ser prestado ao outro" (LACAN, 1972-73, p. 15). Em seu Seminário R.S.I., Lacan (1974-75) chama novamente a atenção para o fato de que, nos falantes, o gozo sexual não é um gozo natural, uma vez que é fálico. Hans serve-lhe mais uma vez de referência para afirmar que, mesmo quando o pequeno menino ainda não sabe exatamente o que fazer com o seu 'Faz-Pipi', isto é, quando ainda parece desconhecer para quê ele serve enquanto órgão reprodutor, o gozo fálico que o envolve o deixa em ereção.

"Assim na psicanálise (porque também no inconsciente), o homem nada sabe da mulher, nem a mulher do homem. No falo se resume o ponto de mito em que o sexual se torna paixão do significante" (LACAN, 1970, p. 410). Que motivos o teriam levado a empregar o 
sintagma "ponto de mito"? Por que não dizer apenas que o falo é mito? Ora, a noção de ponto articula-se bem à de estrutura como algo dotado de extensão. O ponto decide o sentido a ser dado à leitura da estrutura, assim como a Verdrängung da castração decide a escolha da neurose. A equivalência entre o falo e o ponto permite 0 desenvolvimento da ideia de um elemento que foi zerado na psicose, que permaneceu imaginarizado na perversão e, na neurose, passou do imaginário ao simbólico.

Em 14 de maio de 1974, Lacan (apud MOREL, 1995, p. 52) cunhou a expressão "opções da identificação sexuada", a qual se alinha ao termo freudiano "escolha", ao mesmo tempo em que "une, em si, a referência à determinação simbólica e ao gozo". Nessa ocasião, ele ainda observa que "o psicanalista, como o ser sexuado, autoriza-se de si mesmo e de alguns outros". O que equivale a dizer que ele é um-entre-outros, um ser castrado. Pois, como se pode observar, "a função fálica é idêntica à função castração" (MOREL, 2000, p. 123).

\section{O Falo Zerado Na Psicose}

Vejamos, primeiramente, com Antonin $\mathrm{Artaud}^{3}$, o que chamamos com Lacan (1958) "o falo zerado" em consequência da foraclusão do significante do Nome-do-Pai. Em outras palavras, acompanhemos como se pode dar o testemunho genial, por meio da escrita, da invenção de uma sexualidade inédita. Ou seja, uma sexualidade que nada tem a ver com a partilha dos sexos, pela qual um sujeito se diz homem ou mulher.

Aos quinze anos, Artaud não apenas compunha seus primeiros poemas, como já os publicava. Mas, isto não o impediu de se deixar internar em hospital psiquiátrico aos dezoito anos, sob a sugestão de seu pai e por ele conduzido. No entanto, é o próprio Artaud quem nos explica porque o fez: naquela ocasião, o poeta já não podia suportar as dores que o atormentavam em seu corpo e que o tinham "ferido irremediavelmente nos nervos da cabeça". (ARTAUD apud LINS, 1999, p. 79).

Autor de uma vasta obra ${ }^{4}$, que inclui de romances e poesias a roteiros de cinema, muitas cartas e muitos manifestos sobre 0 surrealismo e a arte teatral em geral, Artaud também trabalhou como ator de cinema mudo e diretor de teatro. A problemática do pensamento, como a do grito, é uma constante em sua obra. Alegava que o pensamento o abandonava em todos os níveis e, por esse motivo, precisava estar "constantemente à procura do seu ser intelectual" (ARTAUD, 2004, p. 69) ${ }^{5}$. Considerava com razão que os pensamentos eram os principais responsáveis pelo desajuste entre seus órgãos e seu eu, almejando, então, um corpo sem órgãos. Atormentava-o igualmente a idéia de que jamais poderia morrer, por nunca ter nascido.

Em carta datada de 29 de março de 1946, escreve: 
Há um mistério em minha vida, Marthe Robert, cuja base é que eu não nasci em Marseille em 4 de setembro de 1896, mas que, neste dia, vindo de alhures, passei inteiramente

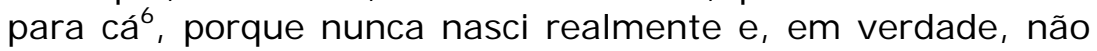
posso morrer. (ARTAUD, 2004, p. 1707).

Como mais um testemunho de sua problemática com o Outro primordial, absoluto e sem lei, podemos citar uma passagem de Suppôts et Suppliciations (Subordinados e Súplicas), um de seus últimos livros. Ele é dividido em três partes: Fragmentations, Lettres e Interjections, compondo-se a primeira de pequenos fragmentos de verso e/ou prosa. No fragmento intitulado "As Mães no Estábulo", Artaud cria, por meio da significação poética, uma causalidade para o seu sentimento de inexistência:

Portas, celas, celeiro, refeição, o quarto que eu tinha que escolher era um celeiro ou um estábulo, um abrigo ou uma prisão?

Era-eu um homem ou um animal?

(...) Antes que eu tivesse tido o tempo de decidir por mim mesmo, o ser de viver me desapossou. Foi assim que as Mães violaram meu pensamento (...) sobreviver é ultrapassar um ser quando este foi estrangulado pela vida. (...) Sísifo, ao subir novamente o rochedo no espírito, não tem mais realidade nos sonhos do que o grito deste terrível AQUI-JAZ, onde Aquele que não existe na vida e que precisa sobreviver para ser, se fez reconhecer por mim em meu sonho quando as Mães me expulsaram da vida (ARTAUD, 2004, p. 1247-9). (Grifos do autor. Trad. nossa).

Irreverente, se é que faz algum sentido a aplicação deste termo à obra escrita de Artaud, nela se lê que é preciso "combater o nepotismo do pau", pois a função de ereção a que se limita o falo só é válida "em efígie ou no abstrato" (ARTAUD apud BRUNO, 1999, p. 51). ${ }^{7}$ Suspeita-se de que o poeta nunca tenha desfrutado do corpo de uma mulher, embora tenha amado algumas. Sua biografia relata que, ao deitar-se com Cécile Schramme, a mulher de quem foi noivo, mas que não chegou a desposar, costumava colocar uma bengala entre os corpos. E ele próprio declara o motivo pelo qual rompeu seu relacionamento com Anaïs Nin: ela não parava de pensar com o sexo. Artaud a intima e convoca: "Para de pensar com teu sexo, absorve enfim a vida, toda a vida, abre-te para a vida, vê as coisas, vê-me, abdica e deixa que a vida me abandone [...] Não me oprimas mais. Basta!" (I bid., p. 80).

Sem o limite fálico que apazigua o desejo e limita o gozo, e que permite a divisão homem/mulher dos seres falantes, o poeta criador do Teatro da Crueldade é levado a escrever que "a Santa Virgem é o Pai-Mãe", mas, em seguida, retifica: "não há Pai-Mãe porque o antagonismo Masculino-Feminino que é da ordem do ser foi suprimido 
com a supressão do $\operatorname{ser}^{\prime 8}$ (ARTAUD apud BRUNO, 1999, p. 115). O empuxo-à-criação que o domina, em particular sob a forma do empuxo-à-escrita, leva-o a exprimir não apenas uma vontade de gozo, como também uma ética singular. "Quero experimentar um feminino terrível", afirma aquele para quem "ser casto é conhecer todas as possibilidades sem perder-se nelas/ser virgem é dominá-las sem as conhecer e viver em espírito acima de tudo" (Ibid., p. 138).

Se a mãe (a Virgem) não é capaz de lhe engendrar um corpo sem passar pela sexualidade e pelo recurso ao pai, perfila-se a tentação de experimentar, por si mesmo, a via da feminização: "Vou terminar, também eu [...] se não tiver outra saída para realizar o desejo carnal, confundindo-me com este feminino" (ARTAUD apud BRUNO, 1999, p. 116). Artaud admira a abelha verde, ou melhor, sua capacidade de produzir todas as "possibilidades não corpo sem homem nem mulheres" ${ }^{\prime \prime}$ (Ibid., p. 127), e declara ter instituído, desde os vinte e dois anos, que "todas as crianças precisariam ser refeitas pelo canal de um sexo infinito, um sexo que não é desse mundo" (Ibid., p. 132). Podemos dizer que Artaud anseia por uma sexuação inédita, a qual só poderia processar-se mediante a partenogênese:

[...] tenho necessidade de um corpo em mim que me responda para produzir uma filha,/este corpo é o meu e eu o fodo em mim, mas é preciso reproduzir essa copulação do lado de fora, para que o ser venha a ser e se conserve ser, sob pena de morte (Ibid., p. 143)

Como observa Derrida (1967), para o inventor do Teatro da crueldade, o termo 'crueldade' não remete necessariamente a 'sadismo', 'horror', 'sangue derramado' ou 'inimigo crucificado', Remete antes a 'rigor', a 'aplicação', 'decisão implacável', 'determinação irreversível', 'determinismo', 'submissão à necessidade'. Mas, que necessidade? De acordo com Bruno (1999), o problema maior com que Artaud se defrontou ao longo de sua vida, como de sua obra, foi fazer nascer um corpo sem passar pela sexualidade. Certamente com o recurso da letra, mas sem o recurso do falo.

\section{O Falo e o desmentido da castração}

E o que dizer daquele cujo "talento perverso" Ihe permite "realizar o único milagre que valha: transmudar o sofrimento em gozo e a falta em plenitude"? (MILLOT, 1996, p. 7) Aos vinte e quatro anos, Yukio Mishima (1925-1970), nascido Kimitaké Hiraoka, publica seu primeiro romance, Confissões de uma máscara. Sucesso imediato de crítica!

Ao inscrevê-lo na fileira de André Gide e de Jean Genet - sob o epíteto "Inteligência da perversão" - Millot (1996) salienta que talvez poucos escritores tenham descrito de forma tão precisa o que 
Freud designou, em 1924, como "masoquismo originário, dito erógeno" (FREUD, 1924, p. 201). Neste, cuja subestrutura é dada por um mecanismo fisiológico característico da infância, a dor confina na excitação sexual. "Quanto a Mishima", prossegue a autora, "os dois focos de seu eu o desmembram entre a cultura e o culturalismo, o homem de letras e o Senhor Músculo" (MILLOT, 1996, p. 13). Apontando para si mesmo o bisturi da análise psicológica, e sem nenhuma pretensão à unicidade, Mishima testemunha "uma duplicidade que é aqui a expressão da honestidade deles (Mishima, Gide e Genet), eles não são pérfidos, mas bífidos, suficientemente falos, decerto, mas sobretudo bicéfalos, tão mitológicos quanto centauros, às vezes tão patéticos quanto o Minotauro" (Idem).

Para a psicanálise, a perversão não é uma simples parada no desenvolvimento, mas um modo específico de defesa frente à castração, uma escolha do sujeito. A opção de desmentir a castração do Outro materno encontra duas vias de processamento: ou o sujeito se identifica com o falo imaginário à frente do véu ou identifica-se com a mãe fálica por trás do véu. Em suma, ou ele se fetichiza ou se traveste.

Isso é o que nos dá a transição entre os casos de fetichismo e os casos de travestismo. O envolvimento não é da ordem do véu, mas da proteção. Trata-se de uma égide, em que se envolve o sujeito identificado com o personagem feminino. (...) As roupas não são feitas apenas para esconder o que se tem, no sentido de ter ou não, mas também, precisamente, o que não se tem. Ambas as funções são essenciais. (LACAN, 1956-57, p. 165 e 169).

Logo nas primeiras páginas de Confissões de uma máscara, Yukio Mishima descreve de forma magistral as lembranças de infância que o atormentaram e assombraram a vida inteira, como dois fantasmas. 0 que elas têm em comum é o fato de despertarem nele a vontade de transformar-se em outro de si mesmo, provavelmente em um Outro da ordem do ideal, pois ela é claramente vontade de gozo. Todavia o afeto que cada uma das lembranças evoca não é o mesmo. Retornaremos a esse ponto adiante.

Mishima tem apenas quatro anos por ocasião da primeira lembrança, porém, a crermos em seus termos, o sujeito criança teria pressentido, desde então, "que neste mundo há um tipo de desejo semelhante à dor pungente" (MISHIMA, 1949/2004, p. 13). Como se impunha a lembrança?

De vez em quando essa imagem voltava, mais intensa, concentrada, e decerto a cada vez acrescida de um novo significado. Isso porque, em meio à cena vaga que a circundava, apenas a figura "daquele que desce a ladeira" emerge com precisão desproporcional [...] Embora ainda não 
fosse capaz de percebê-lo com clareza àquela época, eu havia recebido um chamado misterioso, sombrio, a revelação inicial e alegórica de uma força que se manifestava pela primeira vez na figura daquele limpador de fossas. O excremento é, afinal, um símbolo da terra, e o que me chamava era sem dúvida o amor malevolente da Mãe-Terra. (Ibid., p. 12-13).

A segunda lembrança diz respeito a sua captura pela ilustração que mostrava Joana d'Arc montada num cavalo branco, erguendo uma espada. A criança "acreditava que ele (o cavalo) seria morto em seguida. Se virasse a página depressa, na certa veria seu assassinato." (Ibid. p. 16) Porém um golpe interrompe seus devaneios e fixa a imagem. Uma mulher adulta lhe diz: "Parece homem, não é? Pois é uma mulher!" Nos termos de Mishima, teve lugar a "vingança da realidade", pois "se aquele belo cavaleiro era uma mulher e não um homem, então o que restava?" (I dem).

Uma terceira lembrança produz um amálgama de imagem e odor: são as tropas militares que passam em frente à sua casa, os soldados portam uniformes sujos e botas pesadas, exalam um suor que, misturado à brisa do mar, golpeia as narinas do menino e o deixa como que "embriagado". Esta lembrança tem o mesmo colorido simultaneamente sensual e trágico da primeira, pois, junto ao odor que seduz e excita, há também o destino trágico da profissão de soldado, a morte sempre à espreita, o horizonte longínquo da terra natal (Ibid., p. 17-8).

A quarta lembrança, como a primeira, desperta no menino o desejo de "tornar-se" outra pessoa, outro ser, até mesmo de outro sexo. Fixa-se em sua memória o dia em que entrou às escondidas no quarto da mãe, vestiu o seu quimono mais vistoso, enrolou uma faixa com rosas escarlates pintadas a óleo na cintura, passou pó no rosto e pegou "tudo que ofuscasse a vista com seu brilho" (Ibid., p. 21). Naquele momento, ou melhor, desde aquele momento, Mishima queria ser Tenkatsu, a bailarina cuja figura opulenta "era envolta em trajes semelhantes aos da meretriz do livro do Apocalipse" (Ibid., p. 20). Uma vez paramentada, a criança corre para a sala onde se encontram sua avó doente, a mãe, uma visita e uma criada e grita: "Sou Tenkatsu! Eu, eu sou Tenkatsu!" Mas, quando focaliza o rosto de sua mãe, percebe que ela "estava um pouco pálida, sentada distraidamente, com o pensamento longe" e que "baixou os olhos, quando os olhares se cruzaram". (I bid., p. 21).

Ao refletir sobre 0 encontro de olhares, Mishima escreve: “Compreendi. Lágrimas turvaram minha vista. O que eu havia entendido naquele momento, ou fora obrigado a entender? "Será que o "remorso como prelúdio ao pecado", o leitmotiv dos anos posteriores começava a despontar?" (Idem, ibid.). 
Aos treze anos, sentia-se "uma criança provida de um brinquedo .curioso", que ficava entre as suas pernas e "aumentava de volume à menor oportunidade". Ainda não sabia o que fazer com ele, mas era capaz de perceber que "o brinquedo já possuía um gosto definido e inconfundível, ou seja, obedecia à sua própria ordem." Um brinquedo que "erguia sua cabeça curiosa" tanto ao avistar os jovens com seus corpos à mostra, quanto "em direção à morte, às poças de sangue, à carne rígida." (I bid., p. 33-4).

$\mathrm{O}$ ato mortífero e mortal representa, em Mishima, a única chance do encontro do sexo e do amor. Com ele, o sujeito permanece fixado, cristalizado e detido para sempre no lugar do falo que retorna no real, isto é, do objeto fetiche que simultaneamente atrai e repulsa, fascina e causa horror. Afinal, é o próprio Mishima quem escreve em O templo do pavilhão dourado:

\begin{abstract}
- É gostoso olhar para o nosso objeto. Naquele momento descobri a lógica do meu erotismo, por meio da lógica do aleijado que diz que estar imóvel, também é uma maneira de chegar [...] Ao mesmo tempo em que olho, devo me submeter a ser inteiramente olhado. Ali joguei para fora do meu mundo tanto meu aleijão quanto minhas mulheres [...] Assim, em uma única frase posso definir a grande ilusão a respeito do "amor" neste mundo: é o esforço de juntar a realidade ao fantasma (1956/1988, p. 97-98).
\end{abstract}

Aos quarenta e cinco anos, imediatamente após o término da escrita de $\mathrm{O}$ anjo caído, Yukio Mishima cometeu seppuku ${ }^{11}$, suicídio ritual. Matou-se em nome dos emblemas fálicos que soem representar a tradição e o imperador.

\title{
O gozo do sentido e o significado fálico em um caso de neurose
}

Para exemplificar a função do falo na neurose, abordaremos o caso de um menino de treze anos que chega ao ambulatório público ${ }^{12} \mathrm{com}$ a queixa de ter sido "abusado sexualmente" por um vizinho bem mais velho. A escolha do caso não se justifica pelo trauma real, mas pela forma como o sujeito procurou elaborá-lo, inscrevendo-o no simbólico. Em outros termos, se a experiência traumática anterior ao tratamento havia jogado o sujeito em um gozo difuso e enigmático, configurando o que alguns profissionais de saúde costumam diagnosticar como "síndrome do pânico", só lhe foi possível sair deste lugar mediante o recurso a outros gozos: o gozo do sentido e o gozo fálico.

Miguel relata que foi abusado por um homem que mora em frente à sua casa, trabalha como gari da prefeitura e cria passarinhos para vender. Diz que sempre costumava ir a casa deste na companhia de alguns amigos, para ver ou comprar passarinhos. Porém um dia foi 
só, o homem o amarrou e o ameaçou com um canivete, enquanto abusava dele.

Os pais de Miguel se dizem preocupados com o fato de que, desde esse dia, ele vem se recusando a ir à escola e só dorme com um facão sob o travesseiro. Embora concorde com a observação dos pais acerca das novas condutas com que procura aplacar a angústia, ele não demorará a declinar outras situações que o deixam igualmente angustiado. Entre elas, em especial, alguns ditos parentais.

Nas entrevistas preliminares, Miguel relata que não tem coragem de sair, pois, se tiver que ficar em um lugar fechado com um outro homem, - principalmente em lugares pequenos como elevadores sua "carne treme toda". A insistência do significante "minha carne treme toda", repetido em forma quase compulsiva, deixa ver sua relação com o gozo ignorado e o esforço subjetivo de recobrimento do real com os recursos dos outros registros, isto é, do simbólico e do imaginário. O jovem decide refugiar-se na casa de uma avó que tem um grande galinheiro, entre outros motivos, porque o convívio com os pais está insuportável, já que estes vivem repetindo que "parece que ele está virando viado". Na casa da avó, gosta de afugentar as galinhas e de vê-las fugir aos gritos. Nesse momento, ele certamente se sente fálico, isto é, poderoso. Em outros termos, sustenta um desejo de vingança, em todos os sentidos do termo.

Com o passar do tempo, decide "fazer a cabeça" no centro de Umbanda que a avó freqüenta e traz para a sessão a seguinte fala: "Exu estava atrás de mim para me fazer virar mulher, mas Xangô abriu caminho por trás e soltou meus santos de berço". Os santos vêm sempre aos pares. Explica-me: "Iansã, o vento, vem com Xangô, o dono da pedreira; Ogum, guerreiro, vem com Xangô, justiça etc." Ou seja, eles vêm em pares de oposição e, portanto, estão isentos ao princípio da contradição, denotando sua procedência do inconsciente. Os santos/significantes o ajudam a produzir uma significação sexual para seus impulsos, enigmas e desejos.

Completados aproximadamente três anos desde nosso primeiro encontro, Miguel continua em análise e parece ter menos dúvidas quanto ao sexo próprio. Fala da namorada e prossegue construindo um mito individual de neurótico em que coexistem, paradoxalmente, a crença no significante do encantamento e a aposta no inconsciente. Sua conduta admite duas práticas diferentes: a magia e a psicanálise. Na primeira, a verdade funciona como causa eficiente, na segunda, ela é causa material (LACAN, 1966, p. 890). Isso significa dizer que Miguel se deu conta de que os efeitos eventualmente terapêuticos dos significantes do encantamento não esgotam sua questão de sujeito.

Das questões sobre o sexo, ele passa a questionar a morte, sem se deixar submergir pela tiquê: o exército invade a favela onde mora; um primo, que era como um irmão da mesma idade e que, segundo 
ele, "entrara no tráfico", é assassinado; uma tia de apenas trinta anos morre de câncer em poucos meses. Mas sua carne já não treme toda e sua voz se torna cada vez mais firme. Não resta dúvida de que há um 'em jogo' em seu tratamento e que este pode ser dito o advento da significação fálica da castração, lembrando-nos que

[...] a partir do momento em que somos dois, o ser-para-amorte, não importa no acreditem aqueles que o cultivam, deixa entrever, ao menor lapso, que é da morte do outro que se trata. [...] Mas, em contraste [...] a castração que o sujeito descobre não pode ser senão a sua (LACAN, 1967, p. 363).

\section{Referências Bibliográficas}

ARTAUD, A. Oeuvres. Paris: Éditions Gallimard, 2004.

BRUNO, P. Antonin Artaud. Réalité et poésie. Paris: L'Hartmann, 1999.

CLÉMENT, C. O.; KRISTEVA, J. O feminino e o sagrado. Rio de Janeiro: Rocco, 2001.

DERRIDA, J. (1967). O teatro da crueldade e o fechamento da representação. In: A escritura e a diferença. $2^{a}$ ed. São Paulo: Editora Perspectiva, 1985. p. 149-177.

FREUD, S. (1905). Três ensaios sobre a teoria da sexualidade. In: Edições Standart Brasileira das Obras Psicológicas Completas de Sigmund Freud (ESB), v. 7. Rio de Janeiro: Editora Imago, 1976. p. 123-250.

. (1914). Sobre o narcisismo: uma introdução. In: Edições

Standart Brasileira das Obras Psicológicas Completas de Sigmund Freud (ESB), v. 14. Rio de Janeiro: Editora Imago, 1976. p. 77-110.

. (1923). A organização genital infantil: uma interpolação na teoria da sexualidade. In: Edições Standart Brasileira das Obras Psicológicas Completas de Sigmund Freud (ESB), v. 19. Rio de Janeiro: Editora Imago, 1976. p. 177-186.

(1924). O problema econômico do masoquismo. In: Edições Standart Brasileira das Obras Psicológicas Completas de Sigmund Freud (ESB), v. 19. Rio de Janeiro: Editora Imago, 1976. p. 197-214.

. (1927). Fetichismo. In: Edições Standart Brasileira das Obras Psicológicas Completas de Sigmund Freud (ESB), v. 21. Rio de Janeiro: Editora Imago, 1976. p. 175-187.

(1937). Análise Terminável e Interminável. In: Edições Standart Brasileira das Obras Psicológicas Completas de Sigmund Freud (ESB), v. 23. Rio de Janeiro: Editora Imago, 1976. p. 239-288.

LACAN, J. (1956-57). O Seminário, livro 4: a relação de objeto. Rio 
de J aneiro: J orge Zahar Editor, 1995.

. (1958). A significação do falo. In:

Janeiro: J orge Zahar Editor, 1998. p. 692-703.

Escritos. Rio de

- (dez. 1957-jan. 1958). De uma questão preliminar a todo tratamento possível da psicose. In: Escritos. Rio de Janeiro: Jorge Zahar Editor, 1998. p. 537-590.

. (1966). A ciência e a verdade. In: Escritos. Rio de Janeiro: Jorge Zahar Editor, 1998. p. 869-892.

- (1967). Alocução sobre as psicoses da criança. In:

Outros Escritos. Rio de Janeiro: Jorge Zahar Editor, 2003. p. 359 368

. (1969-70). O Seminário, livro 17: o avesso da psicanálise. Rio de Janeiro: Jorge Zahar Editor, 1992.

(1970). Radiofonia. In: Outros escritos. Rio de Janeiro: Jorge Zahar Editor, 2003. p. 400-447.

. (1972-73). O Seminário, livro 20: mais, ainda. Rio de Janeiro: J orge Zahar Editor, 1985.

. (1974- 75). Seminário R.S.I I I nédito.

LIINSS, D. Antonin Artaud: o artesão do corpo sem órgãos. Rio de J aneiro: Relume-Dumará, 1999.

MILLOT, C. (1996). Gide, Genet, Mishima. Inteligência da perversão. Rio de J aneiro: Companhia de Freud, 2004.

MISHIMA, Y. (1949). Confissões de uma máscara. São Paulo: Cia. das Letras, 2004.

Rocco, 1998.

(1956) O templo do pavilhão dourado. Rio de Janeiro:

MOREL, G. Séminaire Théorique: La différence des sexes. Lille, Bélgica: Association de la Cause Freudienne, 1995.

Ambigüités sexuelles. Sexuation et psychose. Paris: Ed. Ānthropos, 2000.

\section{Endereço para correspondência}

Vera Pollo

Formações Clínicas do Campo Lacaniano. Rua Goethe, 66, Botafogo, CEP 22281-

020, Rio de Janeiro-RJ, Brasil

Endereço eletrônico: verapollo8@gmail.com

Recebido em: 24/06/2009

Aceito para publicação em: 16/04/2010

Acompanhamento do processo editorial: Rita Maria Manso de Barros

\section{Notas}

* Psicóloga do Núcleo de Estudos da saúde do Adolescente do Hospital Universitário Pedro Ernesto (NESA/HUPE/UERJ); Professora do Curso de Especialização em Psicologia Clínica da PUC-RJ e do Mestrado Profissional em Psicanálise, Saúde e Sociedade da Universidade Veiga de Almeida. Psicanalista membro da Escola de 
Psicanálise dos Fóruns do Campo Lacaniano; Coordenadora do Colegiado de Formações Clínicas da Campo Lacaniano - Rio de Janeiro; Doutora e Mestre em Psicologia pela PUC-RJ; D.E.A. pela Universidade de Paris VIII; autora de vários artigos publicados no Brasil e no exterior; Co-organizadora do livro Comunidade Analítica de Escola: a opção de Lacan (Marca D'água Livraria e Editora, 1999) e autora do livro Mulheres Histéricas (Contra Capa Livraria, 2003).

${ }^{1}$ Referimo-nos, aqui, ao que Freud chamou de "rochedos da castração": o repúdio à feminilidade nos homens e a Penisneid, nas mulheres, em "Análise terminável e interminável", 1937.

${ }^{2}$ Ele o deixa muito claro, por exemplo, em sua releitura do caso do Pequeno Hans no decorrer de O Seminário, livro 4: a relação de objeto.

${ }^{3}$ Antoine Marie J oseph Paul Artaud, filho de Antoine Roi Artaud e Euphrasie Nalpas, nasceu em Marseille no dia quatro de setembro de 1896 e foi encontrado morto na manhã de quatro de março de 1948, cerca de um mês depois do término do poema/manifesto Para acabar de vez com o julgamento de Deus. Seus textos mais importantes sobre dramaturgia estão reunidos em $\mathrm{O}$ teatro e seu duplo. $\mathrm{O}$ texto Van Gogh, O suicidado pela sociedade lhe valeu um importante prêmio literário.

${ }^{4}$ Há uma edição de vinte e sete volumes; outra, da Quarto Gallimard, 2004, em volume único de hum mil setecentos e oitenta e seis páginas.

${ }^{5}$ Carta de Artaud ao editor francês Jacques Rivière, em 5 de junho de 1923: "Nots, formes de phrases, directions intérieures de La pensée, réactions simples de l'esprit, jê suis à La poursuite constante de mon être intellectuel".

${ }^{6} \mathrm{Em}$ francês: "J’y suis passé", cuja tradução literal seria: "fui inteiramente consumido".

${ }^{7}$ No original: "Du même corps, le phallus se limite à sa function d'érection, valuable seulement, precise Artaud, 'en effigie et dans l'abstrait'" (VII, 127).

${ }^{8}$ É do próprio Artaud o uso das maiúsculas e do hífen nas palavras: Pai-Mãe e Masculino-Feminino.

${ }^{9}$ No original: "possibilités non corps sans homme ni femmes" (XVI, 51).

${ }^{10}$ No original: “( ...) j'ai besoin d'un corps en moi qui me réponde pour produire une fille, / ce corps est le mien et je le baise en moi, mais il faut reproduire cette copulation dehors afin d'être être et de se conserver être sous peine de mort" (XX, 26). Note-se a insistência da palavra être, ser, que comparece três vezes seguidas.

${ }^{11}$ No ritual seppuku, o suicida corta o ventre com a arma branca e, para que não chegue a sentir dor, é imediatamente decapitado por alguém previamente designado.

${ }^{12}$ Ambulatório do Núcleo de Estudos da Saúde do Adolescente (NESA/HUPE/UERJ). 